\title{
RESPONS TANAMAN LIDAH BUAYA (Aloe vera MILL) TERHADAP BEBERAPA JENIS PUPUK ORGANIK
}

\author{
The response of Aloe Vera (Aloe vera Mill) to some Types of Organic Fertilizer \\ Dyan Respati Puteri, Syaripah Ulpah, Maizar \\ Program Studi Agroteknologi, Fakultas Pertanian Universitas Islam Riau \\ Jl. Kaharudin Nasution 113, Pekanbaru 28284 Riau \\ [Diterima:Januari 2017; Disetujui: April 2017]
}

\begin{abstract}
The purpose of this study was to determine the response of aloe vera plants to several types of organic fertilizers. The design used in this study was a Completely Randomized Design (CRD) with 7 organic fertilizer treatments namely: Without organic fertilizer, chicken manure, cow manure, goat manure, oil palm empty bunch compost, corn bokashi, and vermicelli Each treatment consisted of 5 replications so that there were 35 units of experiment with 4 plants per plot, two of them were used as sample plants, and the whole plant became 140 plants. The parameters observed in this study were the increase in the number of leaf midribs (leaves), leaf width $(\mathrm{cm})$, leaf midrib length $(\mathrm{cm})$, leaf weight (gram), plant biomass (gram) and root volume (ml). The last observation data were analyzed statistically and continued with a BNJ follow-up test at the level of 5\%. Research shows that the response of aloe vera plants to several types of organic fertilizers significantly affects the parameters of leaf width, leaf midrib length, leaf weight, and plant biomass. The best treatment on cow manure with a dose of $50 \mathrm{~g} /$ plant.
\end{abstract}

Keywords: Aloe Vera, Organic Fertilizer

\begin{abstract}
ABSTRAK
Tujuan penelitian ini adalah Untuk mengetahui respons tanaman lidah buaya terhadap beberapa jenis pupuk organik. Rancangan yang digunakan dalam penelitian ini adalah Rancangan Acak Lengkap (RAL) dengan 7 perlakuan pupuk organik yaitu : Tanpa pupuk organik, pupuk kandang ayam, pupuk kandang sapi, pupuk kandang kambing, kompos tandan kosong kelapa sawit, bokashi pelepah jagung dan Kascing. Masing-masing perlakuan terdiri dari 5 ulangan sehingga terdapat 35 unit percobaan dengan 4 tanaman setiap plot, dua tanaman diantaranya dijadikan tanaman sampel, dan keseluruhan tanaman menjadi 140 tanaman. Parameter yang diamati dalam penelitian ini adalah pertambahan jumlah pelapah daun (helai), lebar daun $(\mathrm{cm})$, panjang pelepah daun $(\mathrm{cm})$, berat daun (gram), biomassa tanaman (gram) dan volume akar ( $\mathrm{ml}$ ). Data pengamatan terakhir dianalisis secara statistik dan dilanjutkan dengan uji lanjut BNJ pada taraf 5\%. Penelitian menunjukkan bahwa respon tanaman lidah buaya terhadap beberapa jenis pupuk organik berpengaruh nyata terhadap parameter lebar daun, panjang pelepah daun, berat daun dan biomassa tanaman. Perlakuan terbaik pada pupuk kandang sapi dengan dosis $50 \mathrm{~g} / \mathrm{tanaman}$.
\end{abstract}

Kata kunci: Lidah buaya, Pupuk Organik

\section{PENDAHULUAN}

Lidah buaya pertama kali masuk ke Indonesia sekitar abad ke 17. Tanaman ini dimanfaatkan sebagai tanaman hias, juga sebagai obat luka bakar atau mengatasi kebotakan. Pada dekade 1990-an tanaman ini digunakan dalam industri makanan dan minuman. Kebutuhan lidah buaya untuk bahan baku industri demikian besar. Memang tidak ada angka pasti kebutuhan nasional. Sebagai contoh dari sumber Icano salah satu produsen 
minuman lidah buaya di Jakarta membutuhkan 400 ton per bulan. Belum lagi permintaan industri rumahan, peluang untuk jadi pemasok terbuka lebar apalagi budidaya lidah buaya tidak sulit.

Realisasi ekspor permintaan sejak tahun 2000 sampai Desember 2001 ke Malaysia 303,6 ton $(51,5 \%)$, Hongkong 79,6 ton $(13,5 \%)$ dan permintaan domestik 206,5 ton (35\%). Pada priode Januari sampai Mei 2002 realisasi permintaan turun seperti ke Hongkong menjadi 65 ton (14,9\%), Malaysia 112,5 (25,8\%) sedangkan permintaan domestik menjadi 258,6 ton $(59,3 \%)$, ini membuktikan bahwa permintaan domestik lebih meningkat dari pada permintaan ekspor pada tahun berikutnya (Ahdiat, 2006).

Kotoran sapi dapat dikategorikan sebagai pupuk kompos. Satu ekor sapi dapat menghasilkan pupuk kompos sebesar 23,6 kg per harinya. Sapi dengan berat $227 \mathrm{~kg}$ mampu menghasilkan kotoran sapi dengan kandungan nitrogen sebanyak $28,1 \%$; fosfor $9,1 \%$; dan kalium sebesar $20 \%$. Sapi dengan berat $340 \mathrm{~kg}$ mampu menghasilkan kotoran sapi dengan kandungan nitrogen sebesar 42,2\%; fosfor $13,6 \%$ dan kalium 30\%. Sapi dengan berat 454 $\mathrm{kg}$ mampu menghasilkan kotoran sapi dengan kandungan nitrogen sebesar 56,2\%; fosfor 18,2\%; dan kalium 39,9\%. Pemanfaatan kotoran sapi sebagai pupuk kompos sangat disarankan di dunia pertanian. Pupuk kompos merupakan pupuk organik yang tidak akan menimbulkan dampak negatif bagi tanaman maupun lingkungan alam (Ginaini, 2016).

Pupuk kandang mempunyai kandungan unsur hara berbeda-beda karena masing-masing ternak mempunyai sifat khas tersendiri yang ditentukan oleh jenis makanan dan usia ternak tersebut. Seperti unsur hara yang terdapat pada pupuk kandang sapi yakni N 2,33\%, P2O5 0,61 $\%$, K2O 1,58 \%, Ca 1,04 \%, Mg 0,33 \%, Mn 179 ppm dan Zn 70,5 ppm. Pada pupuk kandang ayam unsur haranya N 3,21\%, P2O5 $3,21 \%$, K2O 1,57 \%, Ca 1,57\%, Mg 1,44\%, Mn 250 ppm dan Zn 315 ppm (Wiryanta dan Bernardinus, 2002).

Unsur hara dalam pupuk kandang kambing N 2,10 \%, P2O5 0,66 \%, K2O 1,97\%, Ca 1,64 \%, Mg 0,60\%, Mn 233 ppm dan Zn 90,8 ppm ( Semekto, 2006). Sedangkan unsur hara pupuk kandang jangkrik adalah $\mathrm{N} 3,80 \%$, P2O5 2,30 \%, K2O 2,70 \%, Ca 2,00\%, Mg
0,66 \%, Mn 197 ppm dan Zn 506 ppm (Analisa Labotarium Universitas Mulawarman). Kandungan unsur hara pada pupuk kandang berbeda-beda, tapi pada prinsipnya, semua jenis pupuk kandang sangat baik untuk tanaman yang terpenting pupuk tersebut harus benar-benar matang, karena pupuk kandang yang tidak matang akan berbahaya bagi tanaman sebab masih mengeluarkan gas selama proses pembusukannya (Prajnanta, 2009).

Pupuk kompos dibuat dari bahan-bahan organik yang telah melalui proses dekomposisi atau bisa dikatakan fermentasi oleh mikro organisme. Tandan kosong kelapa sawit bisa digunakan sebagai bahan dasar pembuatan Pupuk organik atau kompos. Tujuannya adalah agar tidak ada limbah dari industri kelapa sawit yang dibuang ke lingkungan. Kompos dari tandan sawit dapat digunakan ke berbagai tanaman. Tidak hanya daging buah dan inti kelapa sawit saja yang memiliki berbagai macam kandungan nutrisi. Pada sebuah tandan kosong kelapa sawit juga terdapat kandungan nutrisi yang beragam.

Rata-ratanya nutrisi yang terdapat pada tandan kosong kelapa sawit : Nitrogen (N) 0,9 $\%$, Phosphor (P) 0,11 \%, Kalium Potasium (K2O) 2,40 \%, Magnesium (MgO) 0,17\%, Kalsium $(\mathrm{CaO})$ 0,27 \%, Khlor $(\mathrm{Cl})$ 0,44 \%, Mangan (Mg) 24,75 ppm, Boron (B) 12,94 ppm, Zinc (Zn) 37,72 ppm, Copper (Cu) 53,14 ppm dan Besi atau Ferrum 275,36 ppm (Adji putra, 2017).

Tanaman jagung manis mengandung Nitrogen $0,92 \%$, Fosfor 0,29\% dan Kalium 1,39\% (Ruskandi, 2005). Kurangnya prasarana bisa jadi menjadi hambatan dalam mengolah serasah jagung manis yang melimpah. Surtinah (2013) hasil yang diperoleh kompos dengan bahan serasah jagung manis mengandung Karbon 10,5 \%, Nitrogen 1,05 \%, C/N rasio 9,97, Fosfor 1,01 \%, Kalium 0,18 \%, dan Kalsium 1,98 me/100 g.

Kascing adalah pupuk organik yang berupa kotoran cacing yang telah dikeringkan. Kascing berasal dari sampah-sampah organik berupa sayur-sayuran, buah-buahan, daundaunan, kotoran binatang, yang kemudian dimakan oleh cacing dan menjadi pupuk yang mengandung unsur hara yang akan meningkatkan kesuburan dan mudah diserap tanaman. Hal ini terjadi disebabkan kascing tersebut dalam prosesnya telah mengalami 2 
kali proses penguraian. Yang pertama oleh bakteri, yaitu saat sebelum dikonsumsi oleh cacing dan yang kedua oleh cacing itu sendiri, yaitu saat berada dalam perut cacing lalu mengalami penguraian melalui proses metabolik. Pada umumnya, dari hasil pengujian yang dilakukan oleh Sucofindo kandungan hara yang terdapat pada kascing antara lain: nitrogen (N) 1,40\%, fospor (P) 4,33\% dan kalium (K) 1,20\% (Putut Riyadi , 2017).

Pupuk organik tersebut lebih dikenal sebagai kascing (bekas cacing) yang bersifat netral dengan $\mathrm{pH}$ 6,5 - 7,4 dan komponen kimia yang terkandung di dalam kascing diantaranya ialah hormon tumbuh seperti giberelin, sitokinin, auksin dan unsur hara Nitrogen $(\mathrm{N})$ $1,1-4,0 \%$, Fosfor (P) 0,3-3,5\%, Kalium (K) 0,22,\%, belerang (S) 0,24-0,63\%, Magnesium (Mg) 0,3-0,6\%, Besi (FE) 0,4-1,6\% Ca. Kascing mengandung unsur hara yang lengkap, sejumlah mikroorganisme yang bermanfaat dan juga mengandung hormon pengatur tumbuh. Kascing mempunyai kapasitas tukar kation (KTK) yang tinggi sehingga hara yang ada dalam kascing ini dapat cepat tersedia dan dapat dengan cepat diserap oleh akar tanaman (Palungkun,1999 dalam Rizki et al., 2009). Penelitian ini bertujuan untuk mengetahui respons tanaman lidah buaya terhadap beberapa jenis pupuk organik.

\section{BAHAN DAN METODE}

Penelitian ini telah dilaksanakan di kebun percobaan Fakultas Pertanian Universitas Islam Riau, Jalan Kaharudin Nasution KM 11 No. 113 Marpoyan, Kelurahan Air Dingin, Kecamatan Bukit Raya, kota Pekanbaru. Penelitian di laksanakan selama 4 bulan terhitung mulai bulan September sampai Desember 2016.

Adapun bahan yang digunakan dalam penelitian ini adalah bibit tanaman lidah buaya varietas Chinensis, pupuk kandang ayam, pupuk kandang sapi, pupuk kandang kambing, kompos tandan kosong kelapa sawit dan bokashi. Alat yang digunakan adalah cangkul, gunting, pisau, ember, hansprayer, timbangan, polybag, gembor, kamera, meteran, alat tulis, papan merek (triplek, kuas dan paku).

Rancangan yang digunakan dalam penelitian ini adalah Rancangan Acak Lengkap (RAL) dengan 7 perlakuan pupuk organik,
Masing-masing perlakuan terdiri dari 5 ulangan sehingga terdapat 35 unit percobaan dengan 4 tanaman setiap plot. Dua tanaman diantaranya dijadikan tanaman sampel. Perlakuan tersebut adalah: A : Tanpa pupuk organik, B : pupuk kandang ayam dengan dosis $50 \mathrm{~g} /$ tanaman, $\mathrm{C}$ : pupuk kandang sapi dengan dosis 50 g/tanaman, D : pupuk kandang kambing dengan dosis $50 \mathrm{~g} /$ tanaman, $\mathrm{E}$ : kompos tandan kosong kelapa sawit dosis $50 \mathrm{~g} /$ tanaman, $\mathrm{F}$ : bokashi pelepah jagung dengan dosis $50 \mathrm{~g} /$ tanaman, $\mathrm{G}$ : Kascing dengan dosis $50 \mathrm{~g} / \operatorname{tanaman}$. Data hasil pengamatan dari masing-masing perlakuan dianalisis secara statistik dengan menggunakan analisis sidik ragam (ANOVA). Jika $F$ hitung yang diperoleh lebih besar dari $\mathrm{F}$ tabel, maka dilakukan uji lanjut Beda Nyata Jujur (BNJ) pada taraf $5 \%$.

\section{HASIL DAN PEMBAHASAN}

\section{Pertambahan Jumlah Pelapah Daun (helai)}

Hasil pengamatan dilapangan pertambahan jumlah pelapah daun setelah dilakukan analisis ragam menunjukkan bahwa tanaman lidah buaya memiliki respon yang tidak berbeda nyata terhadap beberapa jenis pupuk organik. Data hasil uji lanjut Beda Nyata Jujur (BNJ) pada taraf 5\% dapat dilihat pada tabel 1.

Data pada tabel 1. Menunjukkan bahwa pertambahan jumlah pelapah daun tanaman lidah buaya bervariasi pada setiap jenis pupuk organik yang diberikan. Pertambahan jumlah pelapah daun pada perlakuan pupuk kandang sapi lebih tinggi 12,10 helai dibandingkan dengan tanpa pupuk 11,13 helai, Namun data hasil analisis tidak berpengaruh nyata dengan pemberian beberapa pupuk organik. Pramono (2004) menyatakan bahwa pengaruh bahan organik baru terlihat untuk jangka waktu pemberian yang lama, tergantung sifat biofisik dan jenis tanahnya.

Sumarno (1984) dalam Jumini dan Syammiah (2006) telah menyatakan bahwa tanaman akan tumbuh dengan baik apabila faktor-faktor tumbuh yang diperlukannya berada dalam keadaan optimal, sebaliknya bila keadaan tersebut tidak tersedia dalam keadaan optimal maka pertumbuhan tanaman dan hasil akan terhambat. 
Tabel 1. Rerata pertambahan jumlah pelapah daun, lebar daun dan panjang pelepah daun tanaman lidah buaya terhadap beberapa jenis pupuk organik.

\begin{tabular}{lccc}
\hline $\begin{array}{c}\text { Jenis Pupuk } \\
\text { Organik }\end{array}$ & $\begin{array}{c}\text { Rerata Pertambahan Jumlah } \\
\text { Daun (helai) }\end{array}$ & Rerata Lebar Daun $(\mathrm{cm})$ & $\begin{array}{c}\text { Rerata Panjang Pelepah Daun } \\
(\mathrm{cm})\end{array}$ \\
\hline Tanpa (A) & 11,13 & $3,36 \mathrm{c}$ & $24,90 \mathrm{e}$ \\
Ayam (B) & 12,14 & $4,37 \mathrm{~b}$ & $30,85 \mathrm{c}$ \\
Sapi (C) & 12,10 & $5,41 \mathrm{a}$ & $35,55 \mathrm{a}$ \\
Kambing (D) & 12,05 & $5,28 \mathrm{a}$ & $30,90 \mathrm{c}$ \\
Sawit (E) & 11,88 & $4,30 \mathrm{~b}$ & $30,60 \mathrm{c}$ \\
Jagung (F) & 11,76 & $3,99 \mathrm{~b}$ & $27,50 \mathrm{~d}$ \\
Kascing (G) & 12,09 & $5,38 \mathrm{a}$ & $32,63 \mathrm{~b}$ \\
Rerata Besar & 11,88 & 4,58 & 30,42 \\
\hline KK & $8,05 \%$ & $10,68 \%$ & $5,63 \%$ \\
\hline BNJ & - & 0,42 & 1,48 \\
\hline Ang
\end{tabular}

Angka-angka pada kolom dan baris yang diikuti huruf kecil yang sama tidak berbeda nyata menurut uji lanjut BNJ pada taraf $5 \%$.

\section{Lebar Daun (cm)}

Hasil pengamatan terhadap lebar daun setelah dilakukan analisis ragam menunjukkan bahwa tanaman lidah buaya memiliki respon yang nyata terhadap beberapa jenis pupuk organik. Data hasil uji lanjut Beda Nyata Jujur (BNJ) pada taraf 5\% dapat dilihat pada tabel 1.

Data pada tabel 1 menunjukkan bahwa lebar daun tanaman lidah buaya bervariasi pada setiap jenis pupuk organik yang diberikan. Lebar daun tanaman lidah buaya yang terlebar $5,41 \mathrm{~cm}$ pada perlakuan pupuk kandang sapi yang menyebabkan daun lidah buaya lebih lebar dibandingkan tanpa pemberian pupuk organik.

Lebih lebarnya daun lidah buaya pada pemberian pupuk kandang sapi 50 gram/tanaman disebabkan karena dengan pemberian pupuk kandang dapat membantu ketersediaan unsur hara dalam tanah. Tanpa pemberian pupuk tanaman memiliki ukuran daun lebih kecil karena unsur-unsur yang dibutuhkan dalam proses fisiologi terutama unsure hara yang terkandung di dalam tanah hanya dalam jumlah yang sedikit. Perlunya penambahan unsure hara melalui pemupukan agar tanaman dapat tumbuh dan berkembang dengan hasil yang maksimal. Menurut Agustina (2004) serapan hara yang optimum akan mempengaruhi pembelahan sel, seperti unsur Nitrogen dan Phosfor.

Musnamar (2003) menyatakan bahwa pupuk kandang mengandung unsur hara yang relatif lebih besar dibandingkan kompos, dan ini mungkin menjadi penyebab mengapa pupuk kandang mampu menyuplai hara kepada populasi yang lebih besar daripada kompos.

\section{Panjang Pelapah Daun (cm)}

Hasil pengamatan terhadap panjang pelapah daun setelah dilakukan analisis ragam menunjukkan bahwa tanaman lidah buaya memiliki respon yang nyata terhadap beberapa jenis pupuk organik. Data hasil uji lanjut Beda Nyata Jujur (BNJ) pada taraf 5\% dapat dilihat pada tabel 1.

Data pada tabel 1 menunjukkan bahwa panjang pelapah daun tanaman lidah buaya bervariasi pada setiap jenis pupuk organik yang diberikan. panjang pelapah daun tanaman lidah buaya yang terpanjang $35,55 \mathrm{~cm}$ pada perlakuan pupuk kandang sapi dibandingkan tanpa pemberian pupuk organik.

Pupuk kandang selain mengandung unsur hara juga mengandung enzim, sitokinin dan giberelin (zat pengatur tumbuh) yang dapat merangsang pertumbuhan tanaman (Marsono dan Sigit, 2002).

\section{Berat Daun (gram)}

Hasil pengamatan dilapangan berat daun setelah dilakukan analisis ragam menunjukkan bahwa tanaman lidah buaya memiliki respon yang nyata terhadap beberapa jenis pupuk organik. Data hasil uji lanjut Beda Nyata Jujur (BNJ) pada taraf 5\% dapat dilihat pada tabel 2.

Data pada tabel 2 menunjukkan bahwa berat daun tanaman lidah buaya bervariasi pada setiap jenis pupuk organik yang diberikan. berat daun tanaman lidah buaya yang terberat 142,35 gram pada perlakuan pupuk kandang sapi dan kascing yaitu 137,18 gram, dibandingkan tanpa pemberian pupuk organik. 
Pengukuran terhadap berat segar tanaman merupakan salah satu cara untuk mengetahui laju pertumbuhan suatu tanaman. Laju pertumbuhan dan hasil suatu tanaman, selain ditentukan faktor genetis, juga dipengaruhi oleh faktor lingkungan seperti suhu, air, unsur hara, reaksi tanah dan komposisi udara, kelembaban udara serta hama dan penyakit (Hakim et al, 1986)

Tabel 2. Rerata berat daun, biomassa tanaman dan volume akar tanaman lidah buaya terhadap beberapa jenis pupuk organik.

\begin{tabular}{lrcc}
\hline \multicolumn{1}{c}{ Jenis Pupuk Organik } & Berat Daun $(\mathrm{g})$ & Biomassa Tanaman $(\mathrm{g})$ & Volume Akar $\left(\mathrm{cm}^{3}\right)$ \\
\hline Tanpa (A) & $92,41 \mathrm{~d}$ & $3,37 \mathrm{e}$ & 6,60 \\
Ayam (B) & $130,12 \mathrm{~b}$ & $4,78 \mathrm{~d}$ & 8,20 \\
Sapi (C) & $142,35 \mathrm{a}$ & $8,09 \mathrm{a}$ & 8,80 \\
Kambing (D) & $130,89 \mathrm{~b}$ & $7,26 \mathrm{~b}$ & 7,00 \\
Sawit (E) & $126,31 \mathrm{~b}$ & $6,39 \mathrm{c}$ & 8,60 \\
Jagung (F) & $121,21 \mathrm{c}$ & $5,83 \mathrm{c}$ & 8,80 \\
Kascing (G) & $137,18 \mathrm{a}$ & $8,01 \mathrm{a}$ & 7,40 \\
Rerata Besar & 125,78 & 6,25 & 7,91 \\
\hline KK & $8,24 \%$ & $14,71 \%$ & $14,72 \%$ \\
\hline BNJ & 8,96 & 0,79 & - \\
\hline
\end{tabular}

Angka-angka pada kolom dan baris yang diikuti huruf kecil yang sama tidak berbeda nyata menurut uji lanjut BNJ pada taraf $5 \%$

\section{Biomassa Tanaman $(g)$}

Hasil pengamatan biomassa tanaman setelah dilakukan analisis ragam menunjukkan bahwa tanaman lidah buaya memiliki respon yang nyata terhadap beberapa jenis pupuk organik. Data hasil uji lanjut Beda Nyata Jujur (BNJ) pada taraf 5\% dapat dilihat pada tabel 2.

Data pada tabel 2 menunjukkan bahwa biomassa tanaman lidah buaya bervariasi pada setiap jenis pupuk organik yang diberikan. biomassa tanaman lidah buaya yang terberat 8,09 gram pada perlakuan pupuk kandang sapi dan kascing yaitu 8,01 gram, dibandingkan tanpa pemberian pupuk organik.

Berat kering brangkasan ialah peubah yang penting untuk mengetahui akumulasi biomassa serta imbangan fotosintesis pada masing-masing organ tanaman (Mahmud et,al., 2002). Unsur hara yang tersedia optimum pada suatu tanaman, akan saling mendukung dalam proses fotosintesis, sehingga tanaman dapat menghasilkan berat segar tanaman lobak lebih berat dan berkualitas. Semakin banyak hasil fotosintesis maka semakin banyak pula yang dikirimkan keseluruh keperluan pertumbuhan tanaman lainnya (Jumin, 1989).

\section{Volume Akar $\left(\mathrm{cm}^{3}\right)$}

Hasil pengamatan terhadap volume akar setelah dilakukan analisis ragam menunjukkan bahwa tanaman lidah buaya memiliki respon yang tidak nyata terhadap beberapa jenis pupuk organik. Data hasil uji lanjut Beda Nyata Jujur (BNJ) pada taraf 5\% dapat dilihat pada tabel 2.

Data pada tabel 2 menunjukkan bahwa volume akar tanaman lidah buaya bervariasi pada setiap jenis pupuk organik yang diberikan. volume akar tanaman lidah buaya yang tertinggi $8,80 \mathrm{~cm}^{3}$ pada perlakuan pupuk kandang sapi dan kascing dibandingkan tanpa pemberian pupuk organik, namun tidak signifikan.

Munawar (2010), jumlah hasil produksi yang dihasilkan tanaman memiliki korelasi dengan ketersediaan hara tanah dan tingkat pertumbuhan dan perkembangan tanaman terutama pada bagian akar. Wahyuni (2004) juga menyatakan bahwa dengan optimalnya ketersediaan hara maka pertumbuhan dan perkembangan akar tanaman menjadi optimal yang akan mempengaruhi jumlah hasil produksi tanaman yang dicapai menjadi optimal.

\section{KESIMPULAN}

Dari penelitian yang telah dilakukan dapat disimpulkan bahwa respon tanaman lidah buaya terhadap beberapa jenis pupuk organik berpengaruh nyata terhadap parameter lebar daun, panjang pelepah daun, berat daun dan biomassa tanaman. Perlakuan terbaik pada pemberian pupuk kandang sapi dengan dosis 50 $\mathrm{g} / \mathrm{tanaman}$. 


\section{DAFTAR PUSTAKA}

Adji putra. 2017. 3 Cara Pemanfaatan Tandan Kosong Kelapa Sawit. http://Yuk\%20Simak\%203\%20Cara\%20 Pemanfaatan\%20Tandan\%20Kosong\%2 0Kelapa\%20Sawit!.htm. Diakses tanggal 26 september 2017.

Agustina, L. 2004. Dasar Nutrisi Tanaman. Jakarta: PT Rineka Cipta.

Ahdiat, N. 2006. Lidah Buaya Si Cantik Kaya Manfaat. PT Sinergi. Bandung.

Ginaini. 2016. 9 Manfaat Kotoran Sapi Bagi Pertumbuhan Tanaman. http://9\%20Manfaat\%20Kotoran\%20Sap i\%20Bagi\%20Pertumbuhan\%20Tanaman \%20-\%20Manfaat.co.id.htm. Diakses tanggal 26 september 2017.

Hakim, N., Nyakpa, M.Y., Lubis, A.M., Nugroho, S.G., Diha, M.A., Hong, G.B.,Bailey, H.H. 1986. Dasar-Dasar Ilmu Tanah. Universitas Lampung. 488 hal.

Jumin, H.B. 1989. Ekologi Tanaman, Suatu Pendekatan Fisiologis. Rajawali Pers. Jakarta. 162 hal.

Mahmud, A., B. Guritno dan Sudiarso. 2002. Pengaruh Pupuk Organik Kascing dan Tingkat Air Terhadap Pertumbuhan dan Hasil Tanaman Kedelai (Glycine max L.). J. Agrivita 24 (1): 37-43.

Marsono dan Sigit, P. 2002. Pupuk Akar Jenis dan Aplikasinya. Penebar Swadaya.

Jakarta. Musnamar, E.I. 2003. Pupuk Organik Padat Pembuatan dan Aplikasi. Penebar Swadaya. Jakarta.

Prajnanta. F. 2009. Agribisnis Cabai Hibrida. Penebar Swadaya. Jakarta. Cetakan keenam.

Putut Riyadi. 2017. Pupuk Kascing, Pupuk Organik Terbaik. http://Sadewo\%20Cacing\%20Perkasa\%2 0\%20Pupuk\%20Kascing,\%20Pupuk\%20 Organik\%20Terbaik.htm. Diakses tanggal 26 september 2017.

Rizki, Nurhadi dan Bambang Hermanto. 2009. Pupuk Organik Kascing (Feses cacing). file://Rizki\%20\%20Pupuk\%20Organik\% 20Kascing\%20\%28Feses\%20cacing\%29. htm. Diakses tanggal 26 september 2017.
Ruskandi. 2005. Teknik pembuatan Kompos Limbah Kebun Pertanaman Kelapa Polikultur. Buletin Teknik Pertanain Vol. II. No. 1. Sukabumi.

Wiryanta. W dan Bernardinus .T. 2002. Bertanam Cabai Pada Musim Hujan. Agromedia Pustaka. Jakarta. 
